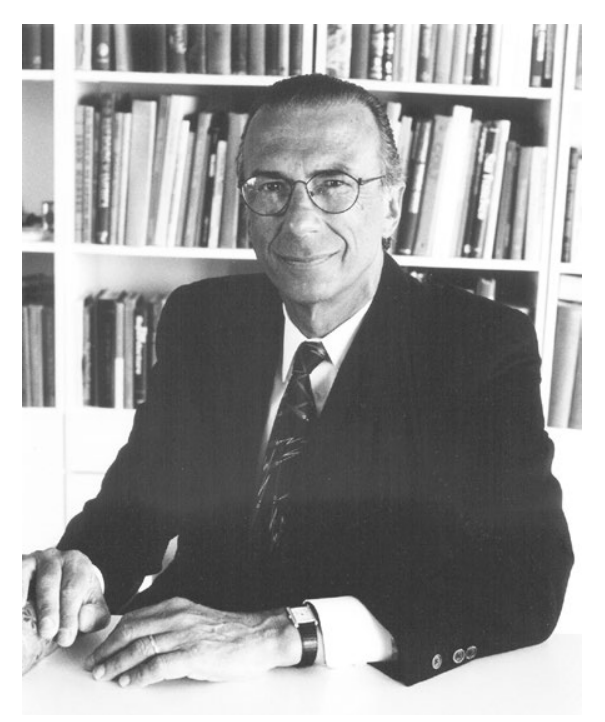

\title{
In Memoriam and Tribute to George Freeman Solomon Professor Emeritus of Psychiatry \& Biobehavioral Sciences, University of California, Los Angeles 1931-2001
}

\author{
D.S. Orlov, M.D.
}

Institute for Experimental Medicine, Saint Petersburg, Russia

"The natural healing force within each one of us is the greatest force in getting well."

Hippocrates

Prof. G.F. Solomon was one of the first scientists to hypothesize that the relationship between brain activity and the body's immune system can be important for determining health and influencing the course of the disease and its outcome. John Solomon is the founder of psychoneuroimmunology, an interdisciplinary field of research into the interaction of the brain, behavior, and immune system that has played a key role in the study of behavioral and biological mechanisms that link psychosocial factors, health, and disease. His research helped to found a new area of knowledge - psychoneuroimmunology, which aims to uncover the mechanisms by which the brain is able to influence the functions of the immune system.

Keywords: psychoneuroimmunology; G.F. Solomon.

\section{В память Джорджа Фримана Соломона почетного профессора психиатрии Калифорнийского университета в Лос-Анджелесе}

\author{
Д.С. Орлов
}

ФГБНУ «Институт экспериментальной медицины», Санкт-Петербург

$$
\begin{array}{r}
\text { «стественная целительная сила в каждом } \\
\text { из нас - величайшая сила в выздоровлении.» } \\
\text { Гиппократ }
\end{array}
$$

Дж. Соломон был одним из первых ученых, выдвинувших гипотезу о том, что взаимосвязь между деятельностью мозга и иммунной системой организма может иметь важное значение для определения состояния здоровья и влияния на течение болезни и ее исход. Дж. Соломон является основателем психонейроиммунологии, междисциплинарной области исследований взаимодействия мозга, поведения и иммунной системы, сыгравшей ключевую роль в исследовании поведенческих и биологических механизмов, связывающих психосоциальные факторы, здоровье и болезни. Его исследования помогли уосновать новую область знания - психонейроиммунологию, которая направлена на то, чтобы раскрыть механизмы, посредством которых мозг способен влиять на функции системы иммунитета.

Ключевые слова: психонейроиммунология; Дж. Соломон. 
G.F. Solomon was among the first scientists to hypothesize about that the relationship between the activities of the brain and the body's immune system may be important in determining health and affecting the course of disease and the health outcomes. When Dr. Solomon began his work, the idea that a healthy mind might help fight cancer and wide range of pathology was largely dismissed by the medical establishment. G.F. Solomon is a founder of psychoneuroimmunology, the interdisciplinary area of research examining interactions between brain, behavior, and the immune system, has played a key role in the exploration of behavioral and biological mechanisms linking psychosocial factors, health, and disease. His work helped to establish the field of psychoneuroimmunology, which is directed to unravel the mechanisms through which the mind can powerfully influence the phenomena of immunity. Initially the two initiatives were complementary and self-reinforcing and have been at the origin of the major in regard to achieving the goals of psychoneuroimmunology. A few pioneering scientists like G.F. Solomon provided new insightful developments well ahead of their colleagues, and independently of the most technologically advanced research tools (1). Most of other researchers, however, had to wait on new technological developments to make essential steps in order to create the progress in behavioral neuroscience and immunology. During the early years of psychoneuroimmunology, skeptics argued that since immune responses can be generated entirely in vitro, innervation must be supportive, rather than essential, for immune responses to develop in vivo. The basic premise of this argument could be flawed, however, if in vitro immune responses are, in fact, not generated entirely in the absence of hormones and neuropeptides. Over the past decades there has been increased scientific as well as public interest in the possible influence of psychological and social factors on human physiology, and a growing body of research has provided evidence for psychosocial influences on both the development and the course of a number of medical illnesses. By challenging the biomedical concept of the immune system as an "autonomous" defense system, psychoneuroimmunology represents a shift from a predominantly biomedical paradigm of health and disease towards an interdisciplinary biopsychosocial approach. Since the early 1980s, the interdisciplinary field of psychoneuroimmunology has explored the complex bi-directional interactions between brain, behavior, and the immune system. The Dr. Solomon's conception of Psychoneuroimmunology has played a key role in creation of knowledge about body and mind interaction. Dr. Solomon's publications describes the development of psychoneuroimmunology and reviews a number of key findings concerning psychological phenomena of potential relevance to un- derstanding brain-behavior-immune interactions, including learning, emotions, stress, and the role of sensory processes.

A pioneer in Psychoneuroimmunology and professor emeritus at UCLA Medical School, where he had been on the faculty for the 18 years passed away on October 8, 2001 at the age of 69. Dr. Solomon had a widely varied and highly influential career which spanned the years after his graduation from Stanford Medical School in 1955. He lectured nationally and abroad and authored over 140 scientific papers and book chapters. Dr. Solomon was a man of international scientific reputation, noted for his keen intelligence, wit and humanity. Lecturing widely across the world, he received many honors including election as a Fellow of the Royal College of Psychiatrists and President of the Psychoneuroimmunology Research Society. Since the early 1980 s, the interdisciplinary field of psychoneuroimmunology has explored the complex bi-directional interactions between brain, behavior, and the immune system [2]. Taken together, this research has expanded the limits of the questions we can ask about the organism by challenging the biomedical paradigm of the immune system as predominantly "autonomous". Psychoneuroimmunology has played a key role in establishing a biological basis for the ancient idea that the mind can play a role in health and disease. George Solomon's works describes the development of psychoneuroimmunology and reviews a number of key findings concerning psychological phenomena of potential relevance to understanding brain-behavior-immune interactions, including learning, emotions, stress, and the role of sensory processes. Collectively, these relationships provide the foundation for previously observed behaviorally-induced alterations in immune function and for immunologically based changes in behavior. They may also provide the means by which psychosocial factors and the emotional states that accompany the perception and response to stressful life experiences influence the development and progression of infectious, autoimmune and neoplastic disease [3]. George F. Solomon was a cofounder and the president of the PsychoNeuroImmunology Research Society during 1997-1998. An international organization for researchers in a number of scientific and medical disciplines, including psychology, neurosciences, immunology, physiology, pharmacology, psychiatry, behavioral medicine, infectious diseases, endocrinology and rheumatology, who are interested in interactions between the nervous and immune systems, and the relationship between behavior and health. An important goal is to conduct basic research that can be translated into clinically relevant health applications. Cooperation in research and innovation is also one of the priority areas for G.F. Solomon. He was convinced that the US and Russia should 
continue to pursue joint-research projects across a number of scientific disciplines to reduce the economic costs of research, benefit from one another's scientific expertise, and increase diplomatic engagement on uncontroversial issues. A worldwide traveler, Professor Solomon is remembered by his friends and colleagues as a great friend, a respected colleague, and a passionate teacher, and he will be dearly missed by all of us in the Institute for Experimental Medicine, Saint Petersburg, Russia community.
George's perspective is better to explain in his own words: "Curiosity, serendipity, psychodynamics, and the ability to put together disparate observations all play roles in the process of scientific discovery. Tenacity, frustration tolerance, and believing the encouragement of some and ignoring the negativism of others play important roles in the fruition of any new observations and theories. The evolution of my contributions to what is now the burgeoning field of psychoneuroimmunology illustrate all these factors."

\section{References}

1. Solomon GF. Psychoneuroimmunology: interactions between central nervous system and immune system. J. Neurosci. Res. 1987;18:1-9.

2. Solomon GF, Ironson GH \& Balbin EG. Psychoneuroimmunology and HIV/AIDS. Annals of the New York Academy of Sciences. 2006;917(1):500-504. https://doi.org/10.1111/j.1749-6632.2000.tb05414.

3. Korneva EA, Rybakina EG, Kokryakov VN, et al. Interleukin-1 and defensins in thermoregulation, stress and immunity. Annals of the New York Academy of Sciences. 1997;812:465-474. 